\title{
Article
}

\section{Non-medical prescribing in primary care in the United Kingdom: an overview of the current literature}

\author{
Armstrong, Amanda, Manfrin, Andrea and Gibson, Josephine \\ Available at http://clok.uclan.ac.uk/39155/ \\ Armstrong, Amanda, Manfrin, Andrea ORCID: 0000-0003-3457-9981 and \\ Gibson, Josephine ORCID: 0000-0002-3051-1237 (2021) Non-medical \\ prescribing in primary care in the United Kingdom: an overview of the current \\ literature. Journal of Prescribing Practice, 3 (9). ISSN 2631-8385
}

It is advisable to refer to the publisher's version if you intend to cite from the work. 10.12968/jprp.2021.3.9.352

For more information about UCLan's research in this area go to http://www.uclan.ac.uk/researchgroups/ and search for <name of research Group>.

For information about Research generally at UCLan please go to http://www.uclan.ac.uk/research/

All outputs in CLoK are protected by Intellectual Property Rights law, including Copyright law. Copyright, IPR and Moral Rights for the works on this site are retained by the individual authors and/or other copyright owners. Terms and conditions for use of this material are defined in the policies page.

\section{CLoK}

Central Lancashire online Knowledge www.clok.uclan.ac.uk

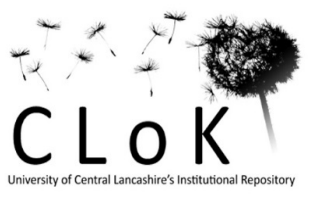


Figure 1 - PRISMA 2009 Flow Diagram
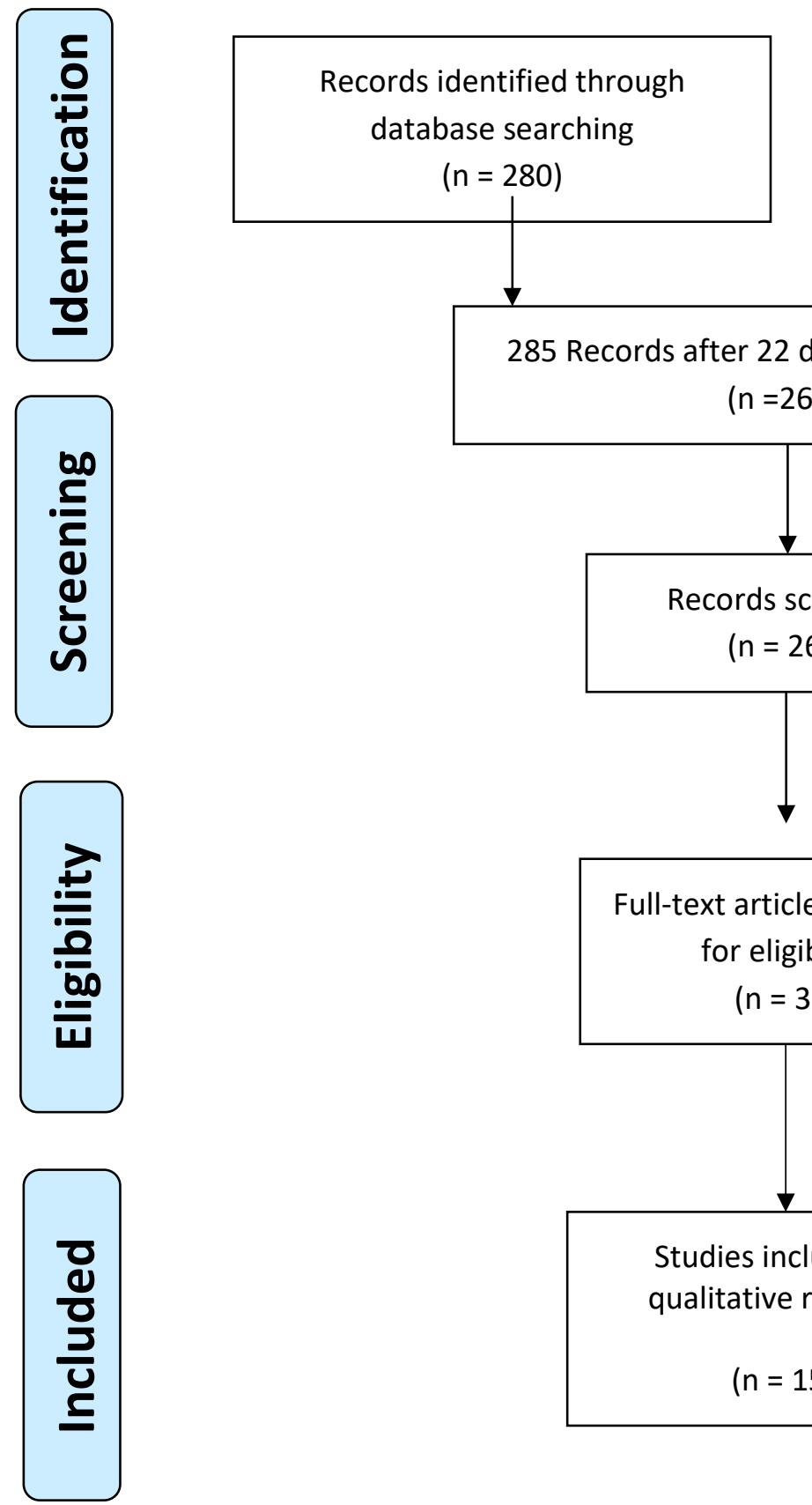

Additional records identified through other sources - citations and recommendations $(n=5)$

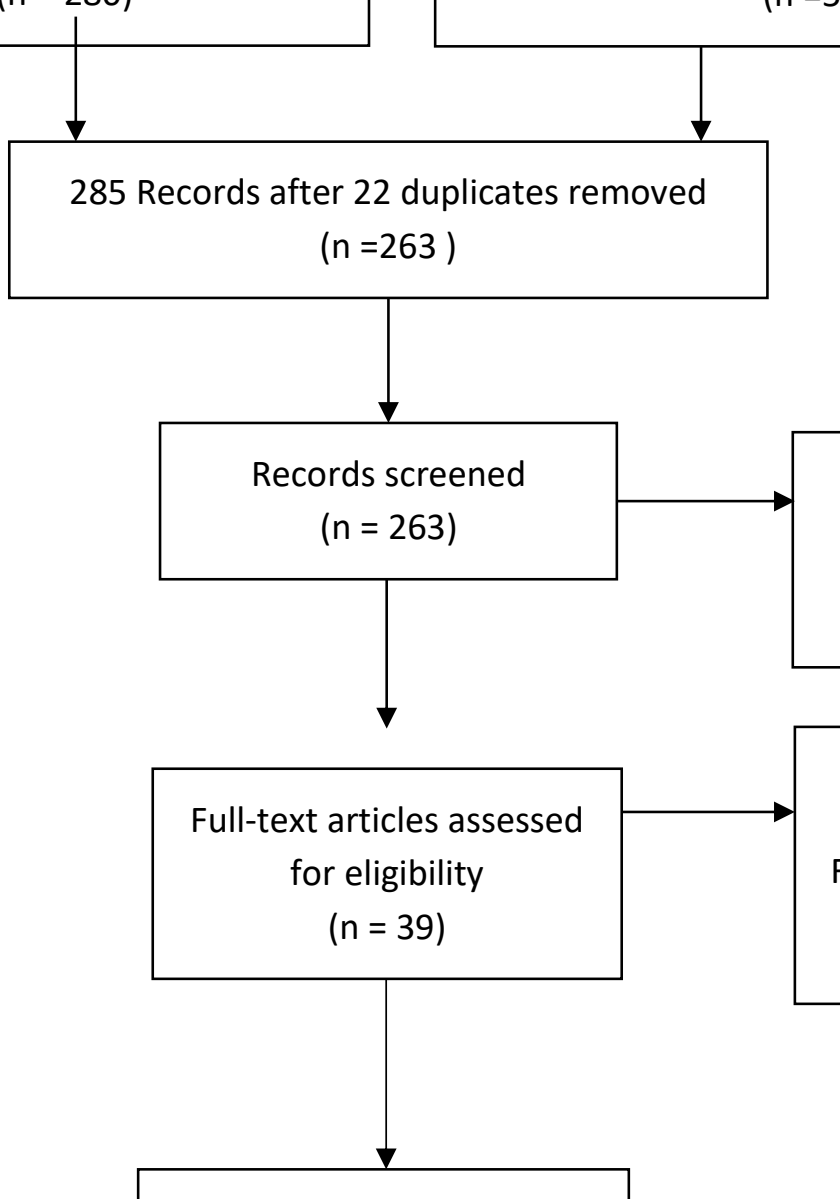

Records excluded

$$
(n=221)
$$

Setting 166

Incomplete 55

Studies included in qualitative research

$$
(n=15)
$$

Review studies excluded

$$
(n=18)
$$

Full-text articles excluded, as narratives, opinions and editorials $(n=9)$ 
